\title{
ESTIMASI KARBON TERSIMPAN PADA HUTAN RAKYAT DI PEKON KELUNGU KABUPATEN TANGGAMUS
}

\section{ESTIMATING COMMUNITY FOREST CARBON STOCK IN PEKON KELUNGU TANGGAMUS DISTRICT}

\author{
Oleh $/ B y$ \\ Liana Ristiara, Rudi Hilmanto, Duryat \\ Jurusan Kehutanan Fakultas Pertanian Universitas Lampung \\ J1. Soemantri Brojonegoro No. 1 Bandar Lampung 35143 \\ Email: lianaristiara@gmail.com \\ No. Handphone : +6282175619913
}

\begin{abstract}
ABSTRAK
Laju degradasi dan deforestasi yang tinggi saat ini menyebabkan berkurangnya simpanan karbon pada lahan hutan. Pekon Kelungu merupakan salah satu desa yang mengembangkan hutan rakyat dengan sistem agroforestri yang juga dapat berfungsi sebagai penyimpan karbon. Penelitian ini dilakukan untuk mengetahui dominansi jenis tanaman pada vegetasi serta menduga besarnya cadangan karbon atas permukaan pada hutan rakyat di Pekon Kelungu. Dominansi tanaman diketahui dengan menghitung Indeks Nilai Penting (INP). Karbon tersimpan dihitung dengan metode alometrik untuk pohon hidup maupun mati, rumus volume untuk nekromasa kayu mati serta rumus Biomass Expansion Factor untuk serasah dan tumbuhan bawah. Tanaman dengan dominansi tertinggi dari fase pohon hingga fase semai yaitu durian, kakao dan cempaka. Total karbon atas permukaan yang tersimpan pada hutan rakyat di Pekon Kelungu yaitu sebesar 101,61 ton/ha. Karbon tersimpan pada komponen pohon yaitu sebesar 99,92 ton/ha, nekromasa yaitu sebesar 0,81 ton/ha, serasah yaitu sebesar 0,87 ton/ha dan tumbuhan bawah yaitu sebesar 0,02 ton/ha.
\end{abstract}

Kata kunci : hutan rakyat, INP, karbon tersimpan

\section{ABSTRACT}

The increasing rates of forest degradation and deforestation has been decreasing carbon stocks of forest. Pekon kelungu is one of the village that developing the community forest using agroforestry system that is also has a function as a carbon stock. The research was conducted to determine the dominant vegetation and to predict the amount of above ground carbon stock at the community forest in Pekon Kelungu. The Important Value Index (IVI) was calculated to measure plants domination. Allometric equation was used to measure carbon stored for living and dead tree, volume formulas for necromass and Biomass Expansion Factor formula for litter and seedlings. Durian, cacao and campaca is the dominat tree pole and seedling, respectively. The total carbon of above ground biomass of community forest in Pekon Kelungu is amounted to 101,61 ton/ha. Carbon stored on tree component is amounted to 99,92 ton/ha, necromass is amounted to 0,81 ton/ha, litter is amounted to 0,87 ton/ha and seedling is amounted to 0,02 ton/ha.

Keyword : carbon stock, community forest, IVI, 


\section{PENDAHULUAN}

Permukaan bumi tengah mengalami pemanasan global yang mengakibatkan terjadinya perubahan iklim. Menurut Hardjana (2010), pemanasan global dapat mengancam kehidupan manusia, yang dipengaruhi oleh peningkatan gas rumah kaca. Karbon dioksida $\left(\mathrm{CO}_{2}\right)$ merupakan salah satu gas rumah kaca yang berpengaruh dalam peningkatan suhu bumi. Butarbutar (2009) menjelaskan bahwa pengurangan konsentrasi $\mathrm{CO}_{2}$ di atmosfer dapat dilakukan melalui penyerapan oleh vegetasi hutan. Vegetasi hutan yang didalamnya terdapat komponen-komponen seperti pohon, nekromasa, serasah, tumbuhan bawah serta bahan organik tanah dapat menyimpan karbon. Menurut Tim Arupa (2014), pohon-pohon dalam hutan merupakan komponen terbesar yang mampu menyerap dan menyimpan $\mathrm{CO}_{2}$.

Pembangunan hutan dalam rangka peningkatan penyerapan $\mathrm{CO}_{2}$ dapat dilakukan pada kawasan hutan negara ataupun hutan hak yang termasuk didalamnya hutan rakyat. Menurut Darusman dan Suharjito (1998), hutan rakyat mempunyai potensi besar baik dari segi populasi pohon maupun jumlah rumah yang mengusahakannya. Hutan yang luas dengan kondisi vegetasi yang baik akan menghasilkan akumulasi penyerapan $\mathrm{CO}_{2}$ yang besar. Akan tetapi dengan adanya laju degradasi dan deforestasi hutan yang tinggi sampai saat ini serapan $\mathrm{CO}_{2}$ telah mengalami penurunan. Hutan yang makin terdegradasi lambat laun akan kehilangan fungsinya sebagai penyerap $\mathrm{CO}_{2}$ (Junaedi, 2008).

Pekon Kelungu merupakan salah satu desa yang mengembangkan hutan rakyat, yang terletak di Kecamatan Kotaagung, Kabupaten Tanggamus. Keberadaan hutan rakyat tersebut diharapkan mampu meningkatkan serapan $\mathrm{CO}_{2}$ ditengah rusaknya kondisi hutan di Provinsi Lampung. Laju kerusakan hutan akibat deforestasi, kebakaran, dan degradasi di Provinsi Lampung sudah mencapai 65,47\% (Dinas Kehutanan Provinsi Lampung, 2013). Belum adanya data mengenai karbon tersimpan pada kawasan hutan rakyat di Pekon Kelungu, maka perlu dilakukan penelitian mengenai karbon tersimpan yang terdapat pada hutan rakyat tersebut. Penelitian ini bertujuan untuk menentukan jenis tanaman dengan INP tertinggi serta menduga besarnya karbon tersimpan pada hutan rakyat di Pekon Kelungu. Dengan adanya data kandungan karbon pada lahan hutan maka dapat dinilai peran dari hutan tersebut dalam menyimpan karbon.

\section{METODE PENELITIAN}

Penelitian ini dilakukan pada bulan Juli hingga September 2015 bertempat di lahan hutan rakyat Pekon Kelungu, Kecamatan Kotaagung, Kabupaten Tanggamus. Objek dalam penelitian ini adalah pohon (semai, pancang, tiang dan pohon), nekromasa, serasah dan tumbuhan bawah yang berada di atas permukaan tanah yang ada di dalam plot pengamatan pada lahan hutan rakyat di Pekon Kelungu, Kabupaten Tanggamus. Alat yang digunakan dalam penelitian ini yaitu tali rafia, tongkat sepanjang 1,3 m, pita meter, christenhypsometer, timbangan, oven, kamera, serta gunting.

Data diambil dengan metode sampling dengan intensitas sampling sebesar 5\% sehingga diperoleh jumlah plot yang akan dibuat yaitu 45 plot pada lahan seluas 36 ha. Sampel ditarik secara simple random sampling karena kondisi vegetasi pada tegakan hutan di lokasi penelitian yang relatif seragam. Plot yang digunakan berukuran $20 \mathrm{~m}$ x $20 \mathrm{~m}$ untuk pohon, $10 \mathrm{~m} \times 10 \mathrm{~m}$ untuk tiang, $5 \mathrm{~m} \times 5 \mathrm{~m}$ untuk pancang dan $2 \mathrm{~m} \times 2 \mathrm{~m}$ untuk semai, serasah dan tumbuhan bawah. 
Data yang di kumpulkan yaitu berupa data vegetasi dan data biomasa. Data vegetasi berupa jenis pohon, diameter pohon dan tinggi pohon dianalisis untuk menghitung kerapatan, kerapatan relatif (KR), frekuensi, frekuensi relatif (FR), dominansi dan dominansi relatif (DR). Dominansi jenis tanaman ditentukan berdasarkan INP dengan menjumlahkan KR, FR dan DR (Michael, 1984). Data biomasa pohon dianalisis dengan persamaan alometrik yang disajikan pada Tabel 1.

Tabel 1. Persamaan alometrik yang digunakan

\begin{tabular}{|c|c|c|c|}
\hline No & Jenis Tegakan & $\begin{array}{l}\text { Persamaan } \\
\text { Allometrik }\end{array}$ & Sumber \\
\hline 1 & Jati * & $\mathrm{BK}=0,015\left(\mathrm{D}^{2} \mathrm{H}\right)^{1,08}$ & Tim Arupa (2014) \\
\hline 2 & Sengon * & $\mathrm{BK}=0,020\left(\mathrm{D}^{2} \mathrm{H}\right)^{0,93}$ & Tim Arupa (2014) \\
\hline 3 & Pohon- pohon bercabang $* *$ & $\mathrm{BK}=0,11 \rho(\mathrm{D})^{2,62}$ & $\begin{array}{l}\text { Ketterings (2001) ; Hairiah dan } \\
\text { Rahayu (2007) }\end{array}$ \\
\hline 4 & Pohon tidak bercabang $* *$ & $\mathrm{BK}=\pi \rho \mathrm{D}^{2} \mathrm{H} / 40$ & $\begin{array}{l}\text { Hairiah (2002) ; Hairiah dan } \\
\text { Rahayu (2007) }\end{array}$ \\
\hline 5 & Kakao & $\mathrm{BK}=0,1208(\mathrm{D})^{1,98}$ & $\begin{array}{l}\text { Yuliasmara dkk. (2009) ; Hairiah } \\
\text { dkk. (2011) }\end{array}$ \\
\hline \multicolumn{4}{|c|}{ Keterangan. } \\
\hline BK & \multicolumn{3}{|c|}{ : berat kering (kg/pohon) } \\
\hline $\mathrm{H}$ & \multicolumn{3}{|c|}{ : tinggi total tanaman $(\mathrm{cm})$} \\
\hline $\mathrm{D}$ & \multicolumn{3}{|c|}{ : diameter setinggi dada $(\mathrm{cm})$} \\
\hline$\rho$ & \multicolumn{3}{|c|}{ : kerapatan kayu $\left(0,7 \mathrm{~g} / \mathrm{cm}^{3}\right)$} \\
\hline
\end{tabular}

Nekromasa berupa pohon mati dihitung dengan menghitung biomasa pohon seperti pada pohon hidup, dikalikan dengan faktor koreksinya (BSN, 2011). Pohon mati tanpa daun memiliki faktor koreksi 0,9, tanpa daun dan ranting memiliki faktor koreksi 0,8 sedangkan tanpa daun, ranting dan cabang memiliki faktor koreksi 0,7. Nekromasa berupa kayu dianalisis dengan rumus berikut (BSN, 2011).

\section{Biomasa $=$ Volume $x$ Berat Jenis}

Data biomasa serasah dan tumbuhan bawah berupa berat basah total, berat basah contoh (sebesar $300 \mathrm{~g}$ ) serta berat kering contoh dianalisis dengan rumus Biomass Expansion Factor berikut (Brown, 1997).

$$
\text { Biomasa }=\frac{\text { berat kering contoh }}{\text { berat basah contoh }} x \text { total berat basah }
$$

Kandungan karbon dihitung dengan mengalikan biomasa pohon, nekromasa, serasah dan tumbuhan bawah dengan 47\% (BSN, 2011). Berdasarkan data tersebut, karbon perhektar pada masing-masing objek dapat dihitung dengan rumus berikut (BSN, 2011).

$$
\text { Karbon } / \text { ha }=\frac{\text { kandungankarbon }}{1000} \times \frac{10000}{\text { luasplot }}
$$

Keterangan.

Kandungan karbon : kandungan karbon masing-masing objek $(\mathrm{kg})$

Luas plot : luas plot pada masing-masing objek $\left(\mathrm{m}^{2}\right)$ 
Karbon total dalam plot dihitung dengan menjumlahkan karbon pada semua komponen seperti pohon, nekromasa, serasah dan tumbuhan bawah. Simpanan karbon/ha total pada lahan hutan rakyat di Pekon Kelungu diperoleh dari rata-rata karbon total pada 45 plot penelitian. Selanjutnya karbon total pada lahan hutan diperoleh dengan rumus berikut (BSN, 2011).

$$
C \text { total }=\left(\frac{\Sigma \text { Cplot }}{n \text { plot }}\right) \times \text { luas areal }
$$

Keterangan.

$C$ total : total cadangan karbon (ton)

n plot : jumlah plot

C plot : total kandungan karbon perhektar (ton/ha)

luas areal : luas total lahan (ha)

\section{HASIL DAN PEMBAHASAN}

\section{A. Indeks Nilai Penting}

Berdasarkan analisis vegetasi yang telah dilakukan pada hutan rakyat di Pekon Kelungu Kabupaten Tanggamus, tanaman yang ditemukan berjumlah 22 jenis dengan komposisi jenis yang cukup beragam pada fase pohon, tiang maupun pancang, namun kurang beragam pada fase semai. Komposisi jenis tanaman penyusun vegetasi hutan rakyat di Pekon Kelungu diantaranya yaitu 17 jenis pada fase pohon, 12 jenis fase tiang, 11 jenis fase pancang dan 2 jenis fase semai. Data tersebut menunjukkan bahwa jumlah jenis tanaman dari fase pohon hingga fase semai cenderung menurun. Kondisi tersebut diduga karena hutan rakyat di Pekon Kelungu merupakan tipe hutan rakyat yang dikelola secara intensif. Petani pada hutan rakyat tersebut melakukan seleksi dan pemilihan jenis pohon yang ditanam sesuai preferensi. Preferensi petani didasarkan atas pengetahuan budidaya dan potensi ekonomi dari jenis tanaman. Petani cenderung menghilangkan jenis-jenis tanaman yang tidak/kurang memiliki nilai ekonomi. Anakan (semai) dari jenis-jenis tanaman yang tidak bernilai ekonomi atau yang terlalu rapat dan berpotensi mengganggu tanaman utama kakao akan dihilangkan.

Nilai penting dari masing-masing jenis tanaman dapat diketahui dengan melakukan penghitungan INP. INP merupakan indikator pentingnya suatu spesies pada habitatnya yang nilainya ditentukan oleh kerapatan, frekuensi dan dominansinya dalam sebuah plot (Wisnu, 2013). INP dari masing-masing jenis tanaman pada hutan rakyat di Pekon Kelungu disajikan pada Tabel 2.

Tabel 2. INP masing-masing jenis tanaman pada hutan rakyat di Pekon Kelungu

\begin{tabular}{lllrrrrr}
\hline No & $\begin{array}{c}\text { Jenis } \\
\text { Tanaman }\end{array}$ & Nama Ilmiah & Pohon & Tiang & Pancang & Semai & Total \\
\hline 1 & Kakao & Theobroma cacao & $13 \%$ & $228 \%$ & $157 \%$ & $0 \%$ & $398 \%$ \\
2 & Cempaka & Michellia champacha & $39 \%$ & $17 \%$ & $40 \%$ & $117 \%$ & $213 \%$ \\
3 & Durian & Durio zibethinus & $95 \%$ & $10 \%$ & $11 \%$ & $0 \%$ & $117 \%$ \\
4 & Melinjo & Gnetum gnemon & $6 \%$ & $2 \%$ & $7 \%$ & $83 \%$ & $99 \%$ \\
5 & Sengon & Paraserianthes falcataria & $13 \%$ & $5 \%$ & $50 \%$ & $0 \%$ & $69 \%$
\end{tabular}




\begin{tabular}{|c|c|c|c|c|c|c|c|}
\hline No & $\begin{array}{c}\text { Jenis } \\
\text { Tanaman }\end{array}$ & Nama Ilmiah & Pohon & Tiang & Pancang & Semai & Total \\
\hline 6 & Duku & Lansium domesticum & $34 \%$ & $4 \%$ & $0 \%$ & $0 \%$ & $39 \%$ \\
\hline 7 & Manggis & Garcinia mangostana & $19 \%$ & $7 \%$ & $8 \%$ & $0 \%$ & $34 \%$ \\
\hline 8 & Kelapa & Cocus nucifera & $29 \%$ & $0 \%$ & $0 \%$ & $0 \%$ & $29 \%$ \\
\hline 9 & Cengkeh & Eugenia aromatic & $7 \%$ & $16 \%$ & $0 \%$ & $0 \%$ & $23 \%$ \\
\hline 10 & Petai & Parkia speciosa & $11 \%$ & $0 \%$ & $6 \%$ & $0 \%$ & $17 \%$ \\
\hline 11 & Jengkol & Pithecellobium lobatum & $6 \%$ & $2 \%$ & $6 \%$ & $0 \%$ & $14 \%$ \\
\hline 12 & Merambung & Vernonia arborea & $6 \%$ & $2 \%$ & $0 \%$ & $0 \%$ & $9 \%$ \\
\hline 13 & Jati & Tectona grandis & $7 \%$ & $0 \%$ & $0 \%$ & $0 \%$ & $7 \%$ \\
\hline 14 & Dadap & Erythrina sp. & $0 \%$ & $0 \%$ & $7 \%$ & $0 \%$ & $7 \%$ \\
\hline 15 & Medang & Litsea sp. & $6 \%$ & $0 \%$ & $0 \%$ & $0 \%$ & $6 \%$ \\
\hline 16 & Randu & Ceiba pentandra & $6 \%$ & $0 \%$ & $0 \%$ & $0 \%$ & $6 \%$ \\
\hline 17 & Salam & Syzygium polyanthum & $0 \%$ & $0 \%$ & $4 \%$ & $0 \%$ & $4 \%$ \\
\hline 18 & Pala & Myristica fragrans & $0 \%$ & $0 \%$ & $3 \%$ & $0 \%$ & $3 \%$ \\
\hline 19 & Ketapang & Terminalia catapa & $0 \%$ & $2 \%$ & $0 \%$ & $0 \%$ & $2 \%$ \\
\hline 20 & Mangga & Mangifera indica & $0 \%$ & $2 \%$ & $0 \%$ & $0 \%$ & $2 \%$ \\
\hline 21 & Nangka & Artocarpus heterophyllus & $2 \%$ & $0 \%$ & $0 \%$ & $0 \%$ & $2 \%$ \\
\hline 22 & Aren & Arenga pinnata & $1 \%$ & $0 \%$ & $0 \%$ & $0 \%$ & $1 \%$ \\
\hline Total & & & $300 \%$ & $300 \%$ & $300 \%$ & $200 \%$ & $1100 \%$ \\
\hline
\end{tabular}

Secara keseluruhan, jenis tanaman yang paling mendominasi pada hutan rakyat di Pekon Kelungu yaitu kakao. Tanaman dengan dominansi tertinggi pada fase pohon yaitu durian, pada fase tiang dan pancang yaitu kakao, sedangkan pada fase semai yaitu cempaka. Menurut Fajri dan Saridan (2012), jenis yang dominan merupakan jenis yang mampu menguasai tempat tempat tumbuh dan mengembangkan diri sesuai kondisi lingkungannya yang secara keseluruhan atau sebagian besar berada pada tingkat yang paling atas dari semua jenis yang berada dalam suatu komunitas vegetasi. Hal tersebut tidak sesuai dengan kondisi yang terjadi pada hutan rakyat di Pekon Kelungu. Dominansi jenis tanaman pada hutan rakyat tersebut bukan ditentukan berdasarkan kesesuaian tempat tumbuh, melainkan karena pengelolaan yang diterapkan oleh petani. Campur tangan manusia pada pengelolaan hutan rakyat ini menunjukkan sistem permudaan yang terjadi merupakan sistem permudaan buatan.

Komposisi jenis tanaman penyusun vegetasi lahan hutan rakyat di Pekon Kelungu meliputi jenis tanaman MPTS, tanaman kayu dan perkebunan. Jenis-jenis tanaman MPTS yang ada pada lahan yaitu cengkeh, duku, durian, jengkol, ketapang, mangga, manggis, melinjo, nangka, pala, petai, randu, salam. Jenis-jenis tanaman tanaman kayu yaitu cempaka, merambung, medang, dadap, jati dan sengon. Jenis-jenis tanaman perkebunan yaitu kakao, kelapa, aren. INP dari masing-masing jenis tanaman tanaman kayu, MPTS serta tanaman perkebunan dapat dilihat pada Gambar 1. 


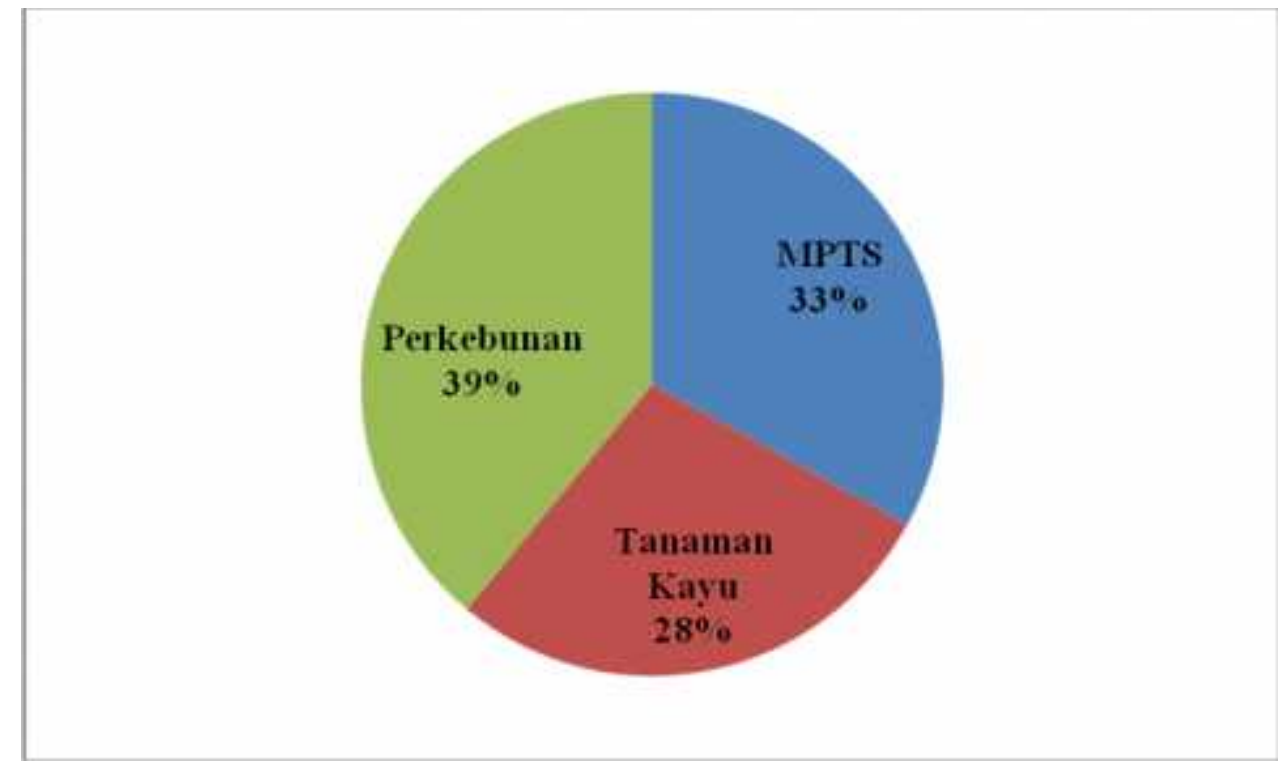

Gambar 1. INP jenis tanaman pada hutan rakyat di Pekon Kelungu

Komposisi tegakan pada hutan rakyat di Pekon Kelungu yang meliputi tanaman perkebunan, tanaman kayu serta tanaman MPTS menunjukkan bahwa sistem pengelolaan yang diterapkan pada hutan rakyat tersebut termasuk dalam sistem agroforestri. Sempitnya penguasaan lahan oleh petani hutan rakyat di Pekon Kelungu menjadikan petani tersebut memilih untuk menanami lahannya dengan berbagai jenis tanaman untuk mengoptimalkan produksi lahan.

Jenis tanaman pada fase pohon baik jenis MPTS maupun tanaman kayu, sebagian besar merupakan jenis pohon intoleran. Hal ini diduga karena petani sengaja memilih jenis pohon sebagai naungan untuk tanaman utama kakao. Petani hutan rakyat di Pekon Kelungu lebih memprioritaskan pertumbuhan tanaman kakao. Jenis pohon yang dipilih pada hutan rakyat tersebut didasarkan dengan kesesuaiannya dengan tanaman kakao.

Selain itu, walaupun selisih INP antar jenis tanaman perkebunan, tanaman kayu dan tanaman MPTS tidak begitu besar namun bila dilihat berdasarkan nilai kerapatan tanaman, tanaman perkebunan jauh lebih rapat dibandingkan dengan jenis lainnya. Jumlah tanaman kakao yang ditemukan pada lahan hutan rakyat di Pekon Kelungu jauh lebih banyak dari jenis tanaman lainnya.

Jenis tanaman MPTS dan tanaman kayu yang jumlahnya jauh lebih sedikit dibandingkan dengan tanaman perkebunan menunjukkan bahwa petani di hutan rakyat tersebut lebih menyukai jenis tanaman perkebunan yaitu kakao. Tanaman kakao sebagian besar berada pada lahan milik rakyat, produksi kakao $89 \%$ berasal dari perkebunan rakyat (Panggabean dan Satyoso, 2008). Selain itu, tanaman tanaman MPTS dan tanaman kayu yang ada pada hutan rakyat di Pekon Kelungu merupakan jenis tanaman pelengkap, bersifat menaungi dan bernilai ekonomi dapat mendukung asumsi bahwa masyarakat lebih menyukai jenis tanaman kakao pada lahannya. 


\section{B. Biomasa dan Karbon Tersimpan}

Estimasi biomasa dan karbon tersimpan pada hutan rakyat di Pekon Kelungu disajikan pada Tabel 3.

Tabel 3. Estimasi Karbon Atas Permukaan pada Hutan Rakyat di Pekon Kelungu

\begin{tabular}{|c|c|c|c|}
\hline Jenis Biomasa & $\begin{array}{r}\text { Biomasa } \\
\text { (ton/ha) }\end{array}$ & $\begin{array}{c}\text { Karbon Tersimpan } \\
\text { (ton/ha) }\end{array}$ & $\begin{array}{c}\text { Persentase } \\
(\%)\end{array}$ \\
\hline $\begin{array}{l}\text { Pohon, Tiang, Pancang dan } \\
\text { Semai }\end{array}$ & 212.59 & 99.92 & 98.33 \\
\hline Nekromasa & 1.72 & 0.81 & 0.80 \\
\hline Serasah & 1.84 & 0.87 & 0.85 \\
\hline Tumbuhan Bawah & 0.04 & 0.02 & 0.02 \\
\hline Total & 216.20 & 101.61 & 100.00 \\
\hline
\end{tabular}

Rata-rata karbon tersimpan pada hutan rakyat di Pekon Kelungu yaitu 101,61 ton/ha sehingga hutan rakyat pada Pekon Kelungu seluas 36 ha dapat menyimpan karbon sebesar 3.658 ton. Simpanan karbon pada hutan rakyat dengan sistem agroforestri di lokasi tersebut lebih rendah dibandingkan hutan dengan sistem agroforestri pada daerah lain. Hasil penelitian di hutan rakyat sistem agroforestri kakao Kabupaten Pesawaran memiliki jumlah karbon tersimpan sebesar 209,64 ton/ha (Natalia dkk., 2014) dan kawasan agroforestri kopi pada hutan lindung Register 39 Datar Setuju Kabupaten Tanggamus menyimpan karbon sebesar 178,24 (Aprianto, 2015). Hairiah dan Rahayu (2007) menyatakan bahwa perbedaan perolehan biomasa dipengaruhi oleh kerapatan vegetasi, keragaman ukuran diameternya dan sebaran berat jenis vegetasinya, dimana penggunaan lahan yang terdiri dari pohon dengan spesies yang mempunyai nilai kerapatan kayu tinggi, biomasanya akan lebih tinggi bila dibandingkan dengan lahan yang mempunyai spesies dengan nilai kerapatan kayu rendah.

Selain itu, Intergovermental Panel on Climate Change (IPCC) (2006) merekomendasikan bahwa angka stok karbon yang tergolong baik pada kategori lahan hutan primer, sekunder dan agroforestri adalah sebesar 138 ton/ha. Besar stok karbon pada hutan rakyat di Pekon Kelungu tidak mencapai 138 ton/ha sehingga dikatakan kurang baik. Rendahnya simpanan karbon pada hutan rakyat di Pekon Kelungu dipengaruhi oleh komposisi tegakan yang didominasi oleh kakao. Seperti pada hutan alami di Sumber Jaya, Lampung Barat yang mengalami penurunan cadangan karbon dari 262 ton/ha menjadi 52 ton/ha hingga 82 ton/ha akibat dikonversi menjadi kebun kopi multistrata dan kebun kopi monokultur (Van Noordwijk dkk., 2002 ; Yuliasmara dkk., 2009).

Cadangan karbon yang tersimpan pada agroforestri hutan rakyat di Pekon Kelungu tidak begitu besar, namun sebagai penyimpan cadangan karbon, sistem penanaman agroforestri kakao ini masih lebih baik dibandingkan hutan tanaman semusim. Menurut Widianto dkk. (2003), walaupun peran agroforestri dalam mempertahankan cadangan karbon di daratan masih lebih rendah dibandingkan dengan hutan alam, tetapi sistem ini dapat memberikan harapan besar dalam meningkatkan cadangan karbon pada lahan-lahan terdegradasi.

\section{Karbon Tersimpan Tanaman Fase Pohon, Tiang, Pancang dan Semai}

Karbon tersimpan pada fase pohon, tiang, pancang dan semai disajikan pada Tabel 4. 
Tabel 4. Rekapitulasi Karbon Tersimpan pada Fase Pohon, Tiang, Pancang dan Semai

\begin{tabular}{|c|c|c|c|c|c|c|}
\hline \multirow{2}{*}{ No } & \multirow{2}{*}{ Jenis Tanaman } & \multicolumn{4}{|c|}{ Karbon (ton/ha) } & \multirow{2}{*}{$\begin{array}{c}\text { Total } \\
\text { (ton/ha) }\end{array}$} \\
\hline & & Pohon & Tiang & Pancang & Semai & \\
\hline 1 & Durian & 35,4182 & 0,9066 & 0,1163 & 0 & 36,4411 \\
\hline 2 & Cempaka & 13,0797 & 1,2934 & 1,1915 & 0,0024 & 15,5670 \\
\hline 3 & Duku & 11,4676 & 0,4670 & 0 & 0 & 11,9346 \\
\hline 4 & Kakao & 0,1662 & 5,3230 & 1,3463 & 0 & 6,8355 \\
\hline 5 & Kelapa & 6,0968 & 0 & 0 & 0 & 6,0968 \\
\hline 6 & Medang & 3,5104 & 0 & 0 & 0 & 3,5104 \\
\hline 7 & Manggis & 2,5750 & 0,7904 & 0,0292 & 0 & 3,3947 \\
\hline 8 & Petai & 3,1849 & 0 & 0,0089 & 0 & 3,1939 \\
\hline 9 & Cengkeh & 1,3762 & 1,4156 & 0 & 0 & 2,7918 \\
\hline 10 & Merambung & 2,3588 & 0,2080 & 0 & 0 & 2,5668 \\
\hline 11 & Randu & 2,3350 & 0 & 0 & 0 & 2,3350 \\
\hline 12 & Jati & 1,1630 & 0 & 0 & 0 & 1,1630 \\
\hline 13 & Sengon & 0,6758 & 0,0836 & 0,2796 & 0 & 1,0390 \\
\hline 14 & Jengkol & 0,6142 & 0,0939 & 0,1556 & 0 & 0,8637 \\
\hline 15 & Nangka & 0,8411 & 0 & 0 & 0 & 0,8411 \\
\hline 16 & Melinjo & 0,5838 & 0,0588 & 0,0770 & 0,0014 & 0,7210 \\
\hline 17 & Aren & 0,2391 & 0 & 0 & 0 & 0,2391 \\
\hline 18 & Ketapang & 0 & 0,2008 & 0 & 0 & 0,2008 \\
\hline 19 & Mangga & 0 & 0,1358 & 0 & 0 & 0,1358 \\
\hline 20 & Dadap & 0 & 0 & 0,0235 & 0 & 0,0235 \\
\hline 21 & Salam & 0 & 0 & 0,0157 & 0 & 0,0157 \\
\hline 22 & Pala & 0 & 0 & 0,0075 & 0 & 0,0075 \\
\hline \multicolumn{2}{|c|}{ Total } & 85,6859 & 10,9770 & 3,2514 & 0,0038 & 99,9181 \\
\hline
\end{tabular}

Berdasarkan Tabel 4, diketahui total karbon tersimpan pada tanaman fase pohon, tiang, pancang dan semai pada hutan rakyat di Pekon Kelungu yaitu sebesar 99,92 ton/ha. Cadangan karbon pada fase pohon yaitu sebesar 85,68 ton/ha, dimana nilai tersebut jauh lebih besar dibandingkan dengan cadangan karbon pada fase tiang, pancang dan juga semai. Menurut Mansur dan Tuhteru (2010), faktor yang mempengaruhi pohon dalam menyerap karbon lebih banyak dibandingkan dengan fase tiang, pancang dan semai yaitu karena umur pohon, dimana semakin tua umur suatu pohon maka akan semakin bertambah diameter dan tinggi pohon tersebut. Selain itu, Putri dan Wulandari (2015) melaporkan bahwa pohon dengan diameter besar dapat menyimpan lebih banyak karbon karena kontribusi utama biomasa yaitu pada batang.

Berdasarkan perolehan INP, jenis tanaman yang paling mendominasi pada hutan rakyat di Pekon Kelungu yaitu tanaman perkebunan, namun jumlah cadangan karbon pada jenis tanaman MPTS dan tanaman kayu lebih besar dibandingkan tanaman perkebunan. Hal tersebut dikarenakan jenis tanaman MPTS dan tanaman kayu yang ada pada hutan rakyat di Pekon Kelungu merupakan pohon-pohon berukuran besar dan berumur panjang. Pohon buahbuahan dan kayu berumur panjang mampu menyimpan karbon lebih banyak bila dibandingkan dengan tanaman semusim (Rahayu dkk., 2010). 


\section{Karbon Tersimpan Nekromasa}

Karbon tersimpan pada komponen nekromasa pada hutan rakyat di Pekon Kelungu yaitu sebesar 0,81 ton/ha. Jumlah karbon nekromasa pada hutan rakyat di Pekon Kelungu termasuk rendah bila dibandingkan dengan daerah lainnya seperti di kawasan hutan lindung Register 39 Datar Setuju Kabupaten Tanggamus, kandungan karbon pada nekromasa mencapai 104,62 ton/ha (Aprianto, 2015).

Hutan rakyat di Pekon Kelungu memilki kondisi yang cukup terawat karena adanya kegiatan pemeliharaan lahan yang cukup intensif sehingga diperoleh kandungan karbon pada nekromasa yang rendah. Selain itu terdapat beberapa warga yang masih memanfaatkan kayu bakar, sehingga mengurangi jumlah kayu/nekromassa dalam lahan hutan.

Sebagian besar nekromasa yang ada merupakan pohon mati yang masih berdiri yang terdiri dari jenis kakao dan jengkol. Beberapa tanaman kakao sengaja dimatikan karena telah terinfeksi hama dan penyakit sehingga tidak menyebar ke tanaman lain. Selain pada pohon mati, karbon nekromasa juga ditemukan pada kayu mati, walaupun dengan jumlah yang sedikit.

\section{Karbon Tersimpan Serasah}

Serasah pada bagian lantai hutan pada hutan rakyat di Pekon Kelungu menyimpan cadangan karbon sebesar 0,87 ton/ha. Simpanan karbon tersebut hanya menyumbang $0,85 \%$ dari total seluruh cadangan karbon tersimpan pada hutan rakyat tersebut. Jumlah tersebut tergolong cukup tinggi apabila disesuaikan dengan cadangan karbon pada komponen lainnya, karena biasanya kandungan karbon serasah tidak lebih besar dari kandungan karbon nekromasa.

Sebagian besar serasah pada hutan rakyat pekon Kelungu merupakan serasah dari tanaman kakao. Tanaman kakao memiliki dominansi dan kerapatan yang tinggi sehingga tanaman tersebut menyumbang banyaknya serasah pada lantai hutan. Agroforestri kakao yang sudah berkembang dapat menjadi sarana konservasi tanah dengan peranan mengintersepsi air hujan dan mengurangi tenaga terpaan (energi kinetik) air hujan dan membentuk lapisan serasah di permukaan tanah (Monde, 2009).

\section{Karbon Tersimpan Tumbuhan Bawah}

Tumbuhan bawah dalam hutan rakyat di Pekon Kelungu menyimpan karbon sebesar 0,02 ton/ha. Jumlah tersebut lebih rendah dibandingkan dengan simpanan karbon pada tumbuhan bawah di Tahura WAR yaitu sebesar 0,88 ton/ha (Yuwono dkk., 2011). Hutan rakyat yang dipelihara secara intensif memiliki jumlah tumbuhan bawah tidak banyak termasuk pada hutan rakyat di Pekon Kelungu. Tumbuhan bawah yang ada dalam hutan rakyat tersebut dibersihkan oleh para petani dalam kegiatan pembersihan lahan.

Secara umum, tumbuhan bawah hanya menyimpan karbon dalam jumlah yang sedikit. Tumbuhan bawah sebaiknya tidak perlu dimasukkan dalam komponen yang diukur dalam mekanisme Reducing Emissions from Deforestation and Forest Degradation (REDD). Kandungan karbon tersimpan yang sedikit pada komponen tumbuhan bawah tidak sebanding dengan usaha dan biaya yang dikeluarkan dalam proses pengukurannya. Menurut Manuri dkk. (2011), tumbuhan bawah di lantai hutan yang relatif sedikit dapat dikeluarkan dari perhitungan, sehingga dalam pengukuran karbon atas permukaan, biomasa yang diukur yaitu biomasa pohon, biomasa nekromasa, dan biomasa serasah. 


\section{KESIMPULAN}

Berdasarkan analisis vegetasi yang telah dilakukan pada hutan rakyat di Pekon Kelungu ditemukan 22 jenis tanaman. Dominansi tanaman pada hutan rakyat di Pekon Kelungu yang tertinggi pada fase pohon yaitu durian, pada fase tiang dan pancang yaitu kakao dan pada fase semai yaitu cempaka. Total karbon atas permukaan yang tersimpan pada hutan rakyat di Pekon Kelungu sebesar 101,61 ton/ha yang terdiri dari karbon pohon sebesar 99,92 ton/ha, karbon nekromasa sebesar 0,81 ton/ha, karbon serasah sebesar 0,87 ton/ha dan karbon tumbuhan bawah sebesar 0,02 ton/ha.

\section{DAFTAR PUSTAKA}

Aprianto, D. 2015. Karbon Tersimpan pada Kawasan Sistem Agroforestry di Register 39 Datar Setuju KPHL Batutegi Kabupaten Tanggamus. Skripsi. Universitas Lampung. Bandar Lampung. 87p.

Badan Standardisasi Nasional (BSN). 2011. Pengukuran dan Penghitungan Cadangan Karbon. Pengukuran Lapangan untuk Penaksiran Cadangan Karbon Hutan (Ground Based Forest Carbon Accounting). Buku. Badan Standardisasi Nasional. Jakarta. 16p.

Brown, S. 1997. Estimating Biomass and Biomass Change of Tropical Forest, a primer. Buku. FAO Forestry Paper 134. FAO Rome. 55p.

Butarbutar, T. 2009. Inovasi manajemen kehutanan untuk solusi perubahan iklim di Indonesia. Jurnal analisis kebijakan kehutanan (6) (2) : 121-129.

Darusman, D. dan D. Suharjito., 1998. Kehutanan Masyarakat: Beragam Pola Partisipasi Masyarakat dalam Pengelolaan Hutan. Buku. Institut Pertanian Bogor. Bogor. 150p.

Dinas Kehutanan Provinsi Lampung. 2013. Rencana Pengelolaan Hutan Jangka Panjang Kesatuan Pengelolaan Hutan Lindung (KPHL) Batutegi 2014-2023. Buku. Dinas Kehutanan Provinsi Lampung. Lampung. 74p.

Fajri, M. dan A. Saridan. 2012. Kajian ekologi parashorea malaanonan merr di hutan penelitian labanan Kabupaten Bera. Jurnal Penelitian Dipterokarpa 6 (2) : 141-154.

Hairiah, K., A. Ekadinata, R. R. Sari., S. Rahayu. 2011. Pengukuran Cadangan Karbon Dari Tingkat Lahan ke Bentang Lahan. Buku. World Agroforestry Centre-ICRAF. Bogor. $87 \mathrm{p}$.

Hairiah, K. dan S. Rahayu. 2007. Pengukuran Karbon Tersimpan di Berbagai Penggunaan Lahan. Buku. World Agroforestry Center-ICRAF. Bogor. 77p.

Hardjana, A. K. 2010. Potensi biomassa dan karbon pada hutan tanaman Acacia mangium di HTI PT. Surya Hutani Jaya, Kalimantan Timur. Jurnal Penelitian Sosial dan Ekonomi Kehutanan 7 (4) : 237-249. 
Intergovermental Panel on Climate Change (IPCC). 2006. Intergovermental Panel on Climate Change Guidelones for National Greenhouse Gas Inventories : Bab 5. Buku. Published: IGES, Japan. 32p.

Junaedi, A. 2008. Kontribusi hutan sebagai rosot karbondioksida. Jurnal Info Hutan 5 (1) : $1-7$.

Manuri, S., C.A.S. Putra dan A.D. Saputra. 2011. Teknik Pendugaan Cadangan Karbon Hutan. Buku. Merang REDD Pilot Project, German International Cooperation (GIZ). Palembang. 91p.

Mansur, I. dan F. D. Tuhteru. 2010. Kayu Jabon . Buku. Penebar Swadaya. Jakarta. 129p.

Michael, P. 1984. Metode Ekologi Untuk Penyelidikan Lapangan dan Laboratorium. Buku. Universitas Indonesia Press. Jakarta. 616p.

Monde, A. 2009. Degradasi Stok Karbon (C) Akibat Alih Guna Lahan Hutan Menjadi Lahan Kakao Di Das Nopu, Sulawesi Tengah. J. Agroland 16 (2) : 110—117.

Natalia, D., S.B. Yuwono dan R. Qurniati. 2014. Potensi penyerapan karbon pada sistem agroforestri di Desa Pesawaran Indah Kecamatan Padang Cermin Kabupaten Pesawaran Provinsi Lampung. Jurnal Sylva Lestari. 2 (1): 11-20.

Panggabean, T. R. dan H. U. Satyoso. 2008. Kakao Manajemen Agrobisnis dari Hulu hingga Hilir : Perdagangan. Buku. Penebar Swadaya : Bogor. 364p.

Putri, A.H.M. dan C. Wulandari. 2015. Potensi penyerapan karbon pada tegakan damar mata kucing (Shorea javanica) di Pekon Gunung Kemala Krui Lampung Barat. Jurnal Sylva Lestari 3 (2) : 13-20.

Rahayu, S., M. V. Noordjwik dan B. Lusiana. 2010. Pendugaan Cadangan Karbon di Atas Permukaan Tanah pada Berbagai Sistem Penggunaan Lahan di Kabupaten Nunukan, Kalimantan Timur. World Agroforestry Centre. Bogor. 88p.

Tim Arupa. 2014. Menghitung Cadangan Karbon di Hutan Rakyat Panduan bagi Para Pendamping Petani Hutan Rakyat. Buku. Biro Penerbit Arupa. Sleman. 28p.

Wisnu, I. G. R., I. P. G. Ardhana dan G. Wijana. 2013. Penghitungan nilai karbon pada kawasan hutan di Provinsi Bali. Jurnal AGROTROP, 3(1): 43-53.

Widianto, K. Hairiah., D. Suharjito., M. A. Sardjono. 2003. Fungsi dan Peran Agroforestri. Buku. World Agroforestry Centre (ICRAF). Bogor. 37p.

Yuliasmara, F., A.Wibowo dan A. A.Prawoto. 2009. Karbon tersimpan pada berbagai umur dan sistem pertanaman kakao : persamaan alometrik. Pelita Perkebunan 25(2): 86100 .

Yuwono, S. B., R. Qurniati dan R. Hilmanto. 2012. Estimasi Total Penyerapan Karbon Tersimpan pada Sistem Agroforestri di Desa Sumber Agung Untuk Mendukung Rencana Aksi Nasional Gas Rumah Kaca. Prosiding Seminar Nasional Agroforestri III, 29 Mei 2012. Universitas Lampung. Bandar Lampung. 87—91. 